\title{
Aktualitások az útépítésben hasznosítható másodlagos nyersanyagok területén
}

\author{
Udvardi Bella ${ }^{1}$, Géber Róbert ${ }^{1}$, Kocserha István ${ }^{1}$ \\ ${ }^{1}$ Kerámia- és Polimermérnöki Intézet \\ e-mail: ubella07@gmail.com; robert.geber@uni-miskolc.hu; \\ istvan.kocserha@uni-miskolc.hu
}

\begin{abstract}
Kivonat Az útépítési technológiában a legelterjedtebben használt anyag az aszfaltbeton, amelynek előállításához nélkülözhetetlen alapanyagok a primer kózetek. A folyamatos építóipari célú felhasználásnak köszönhetóen a természetes ásványi anyagok mennyisége világszerte kimerülóben van. Magyarország természetföldrajzi adottságaiból fakadóan jó minóségú ásványvagyonnal rendelkezik, azonban néhány évtized múlva az ásványkincsek kitermelése gondot okozhat, esetleg a készletek kimerüléséhez vezethet. Mindezen okok miatt megnótt az igény olyan potenciális anyagok keresésére, amelyek segítségével az ásványi nyersanyagok részben vagy teljes egészében helyettesíthetók. Ilyen anyagok lehetnek a különbözó ipari folyamatok során keletkezó másodlagos nyersanyagok. Jelen cikk célja az aktuális trendek, kutatási eredmények összefoglaló bemutatása.

Kulcsszavak másodlagos nyersanyagok, meddó, pernye, salak, építési és bontási hulladék
\end{abstract}

\section{Current issues in recoverability of secondary raw materials used for road construction}

\begin{abstract}
Asphalt concretes, essentially produced from primary rocks, are the most widespread used materials in road construction. As a result of continuous use for construction purposes, the quantity of natural raw minerals are worldwide exhausting. Hungary, due to its geographical conditions, is rich in these good quality raw materials, however the extraction of minerals may cause the exhausting of the resources after a few decades. Therefore, the demand for searching potential materials to substitute mineral resources was grown. Secondary raw materials from different industrial processes may be a kind of these materials. The aim of this study is to present a summary of current research trends and results.

Keywords secondary raw materials, tailings, fly ash, slag, construction and demolition
\end{abstract}

\section{Udvardi Bella}

Miskolci Egyetem, Kerámia- és Polimermérnöki Intézet, PhD-hallgató. Okleveles anyagmérnök. Kutatási terület: építóanyagok

\section{Dr. Géber Róbert}

Miskolci Egyetem, Kerámia- és Polimermérnöki Intézet, egyetemi adjunktus. Okleveles anyagmérnök. Kutatási terület: építôanyagok, reológia

\section{Dr. Kocserha István}

Miskolci Egyetem, Kerámia- és Polimermérnöki Intézet, intézetigazgató, egyetemi docens. Okleveles gépészmérnök. Kutatási terület: hagyományos- és múszaki kerámiák, építőanyagok 


\section{Bevezetés}

A fogyasztói társadalom és a szükségletek folyamatos kielégítése következtében nagy mennyiségú hulladék termelődik a gazdaság különböző ágazataiban. Az ipari gyártási folyamatok során keletkező maradványok elhelyezése jellemzóen hulladéklerakóban történik, azonban a deponálás - ezen anyagok nagy mennyiségben történó folyamatos termelődése miatt - nem jelent végleges megoldást, valamint gazdasági és környezetvédelmi szempontból sem elónyös.

Az útépítési technológia megfeleló potenciállal rendelkezik ahhoz, hogy az ipari különbözó melléktermékek hasznosíthatók legyenek. Az utóbbi években a fenntarthatóság fontos szerepet tölt be a társadalmi életben, ezáltal az útpályaszerkezetek építése során is a környezetbarát gyártási folyamatokra törekednek. Sok esetben központi szerepet tulajdonítanak a magas újrahasznosítási aránynak, ezzel ügyelve a karbon lábnyom minimalizálására. Ennek következtében számos kutatás [1-4] foglalkozik különbözó melléktermékek útépítésben történő újrahasznosíthatóságával. Magyar szakemberek közremúködésével a 2000-es évek elsố felében egy hiánypótló mú is elkészült az útépítésben hasznosítható másodlagos nyersanyagokkal kapcsolatosan [5]. Az azóta eltelt 14 évben a technológiai fejlődésnek köszönhetốen új kutatási eredmények születtek a különböző másodlagos nyersanyagok, illetve hulladékok útépítésben történó alkalmazásának témakörében. Éppen ezért a téma aktualitása miatt a Szerzốk célszerúnek látják összefoglalni, ismertetni a legújabb kutatási eredményeket, ismereteket.

Közismert, hogy az aszfaltkeverék két fó összetevốje a kôváz és az a kötôanyag, amely biztosítja a kốzetszemcsék teljes egészében történő bevonását, illetve a felületükhöz történó tapadást. Az aszfaltkeverékek készítéséhez szükséges primer kôzetek helyettesítése lehetséges különbözố újrahasznosított anyagokkal. Ugyanakkor további kutatások kérdése az, hogy ezeket az alternatív anyagokat hogyan és milyen arányban lehetne kombinálni egymással úgy, hogy képesek legyenek biztosítani az elvárt minóségi követelményeket.

Ahhoz, hogy a keletkezett hulladékok felhasználhatók legyenek útépítési területen, a belólük készített aszfaltoknak hasonló, esetleg jobb minôségi tulajdonságokkal kell bírniuk a hagyományos utaknál. Néhány fontos elvárás, amelynek eleget kellene tenniük:

- elegendő mennyiségú anyag rendelkezésre állása;

- megfelelô hulladékkezelési és hasznosítási eljárás létrehozása;

- hasonló vagy jobb teljesítményú pályaszerkezet építése a hagyományos utaknál.

Fontos megjegyezni, hogy azon ipari melléktermékek hasznosítása gazdaságos, amely nem vagy alig igényel elókészítési eljárást. Mindemellett az újrahasznosítani kívánt anyagoknak szabványos minốségi követelményeknek és környezetvédelmi elóírásoknak is eleget kell tenniük. A következő fejezetekben bemutatásra kerülő tudományos eredmények megerôsítik, hogy a számos hulladék anyag alkalmazása jó, illetve sok esetben még jobb eredményeket produkál a természetes ásványi anyagoknál.

\section{Másodlagos nyersanyagok az útépítésben}

Ebben a fejezetben a másodlagos anyagok négy nagy csoportját mutatjuk be (bányászati meddő, erốmúi pernye, kohászati salak, építési-és bontási anyagok). Ezek közül a leginkább ismert az erômúi pernye, amellyel a szakirodalom már széles körben foglalkozott. Az 1. táblázat definíció szerint ismerteti az egyes típusokat.

A 2. táblázat a rendelkezésre álló szakirodalmi források ismereteit összegyújtve mutatja be a különbözố másodlagos nyersanyagok útépítési célra történố alkalmazásainak aktuális eredményeit. Megfigyelhető, hogy az erômúi pernyét az útépítô ipar számos területén alkalmazták már. Ezen kívül elterjedten alkalmazott a melléktermékként keletkezô kohászati salak is (3. táblázat).

\section{1. táblázat Másodlagos nyersanyagok fajtái definíció szerint [5-9]}

\begin{tabular}{|c|c|c|c|}
\hline Bányászati meddók & Erómúi pernye & Kohászati salakok & Építési és bontási hulladékok \\
\hline $\begin{array}{l}\text { Az ásványi nyersanyagok bányá- } \\
\text { szata és elókészítése során nagy } \\
\text { mennyiségú meddó, illetve mara- } \\
\text { dék anyag keletkezik, melyek nem } \\
\text { vagy csak minimális mennyiség- } \\
\text { ben tartalmazzák az elsődleges } \\
\text { termelési célként megjelölt } \\
\text { anyagot. }\end{array}$ & $\begin{array}{l}\text { Az erómúi pernye a szenek elége- } \\
\text { tésekor keletkezó heterogén, por- } \\
\text { szerú, túlnyomó részt amorf (üve- } \\
\text { ges) maradék anyag. }\end{array}$ & $\begin{array}{l}\text { A kohászati salakok (ipari kózet) a } \\
\text { fém olvasztása során az ércek } \\
\text { meddó alkotórészeinek, illetve a } \\
\text { fémolvadékból eltávolítandó nem- } \\
\text { kívánatos olyan vegyületek, me- } \\
\text { lyek folyékony állapotban } \\
\text { keletkeznek, majd lehúlve } \\
\text { megdermednek. }\end{array}$ & $\begin{array}{l}\text { Az építési hulladék körébe tarto- } \\
\text { zik az épületek és az építmények } \\
\text { létesítése, felújítása, illetve bontá- } \\
\text { sa folyamán keletkezó szilárd hul- } \\
\text { ladékok összessége. Ide sorolják a } \\
\text { kitermelt földet, az épületek és } \\
\text { építmények bontási törmelékét, } \\
\text { ide tartozik az útbontási törmelék, } \\
\text { valamint az építési munkahelyi } \\
\text { hulladék (fa, papír, múanyagok, } \\
\text { fémek stb.) is. }\end{array}$ \\
\hline
\end{tabular}




\section{2. táblázat. Útépítésben újrahasznosított anyagok}

\begin{tabular}{|c|c|c|c|c|c|c|c|c|c|c|}
\hline \multicolumn{2}{|c|}{ Újrahasznosított anyagfajta } & \multicolumn{3}{|c|}{ Földmúalap } & \multicolumn{2}{|l|}{ Földmú } & \multicolumn{4}{|c|}{ Útpályaszerkezeti réteg } \\
\hline & & $\begin{array}{l}\text { Tömörített } \\
\text { altalaj }\end{array}$ & $\begin{array}{l}\text { Földmú- } \\
\text { alapozási } \\
\text { réteg }\end{array}$ & $\begin{array}{l}\text { Szivárgó } \\
\text { réteg }\end{array}$ & Töltéstest & $\begin{array}{l}\text { Földmú } \\
\text { felsôrész }\end{array}$ & $\begin{array}{l}\text { Burkolat- } \\
\text { alap réteg }\end{array}$ & $\begin{array}{l}\text { Aszfalt } \\
\text { alapréteg }\end{array}$ & $\begin{array}{l}\text { Aszfalt } \\
\text { kötóréteg }\end{array}$ & $\begin{array}{l}\text { Aszfalt } \\
\text { kopóréteg }\end{array}$ \\
\hline \multirow[t]{3}{*}{$\begin{array}{l}\text { Bányászati } \\
\text { meddő }\end{array}$} & $\begin{array}{l}\text { Rézbányászati } \\
\text { meddó }\end{array}$ & - & - & - & - & - & {$[10]$} & {$[10]$} & - & - \\
\hline & Magnetit & - & - & - & - & - & {$[11]$} & - & - & {$[12]$} \\
\hline & $\begin{array}{l}\text { Olajfúrásból } \\
\text { származó tisztí- } \\
\text { tott meddó }\end{array}$ & - & - & - & - & - & - & - & {$[13]$} & - \\
\hline \multicolumn{2}{|c|}{ Erómúi pernye } & {$[14]$} & {$[14,15]$} & {$[16]$} & $\begin{array}{l}{[14,17,} \\
18]\end{array}$ & - & {$[19-23]$} & - & {$[24,25]$} & - \\
\hline \multirow[t]{2}{*}{$\begin{array}{l}\text { Kohászati } \\
\text { salakok }\end{array}$} & $\begin{array}{l}\text { Elektroacélmúi } \\
\text { salak }\end{array}$ & - & - & - & - & - & {$[10,26]$} & {$[10,33]$} & - & {$[27]$} \\
\hline & Alumínium salak & - & - & - & {$[28]$} & - & - & - & - & {$[29]$} \\
\hline \multirow{4}{*}{$\begin{array}{l}\text { Építési, } \\
\text { bontási } \\
\text { hulladék }\end{array}$} & Téglaórlemény & {$[30]$} & [15] & - & - & - & - & [31] & - & {$[32]$} \\
\hline & Bontott beton & - & - & - & - & - & - & [33] & {$[34]$} & - \\
\hline & $\begin{array}{l}\text { Visszanyert } \\
\text { martaszfalt }\end{array}$ & - & - & - & - & - & - & - & {$[35]$} & {$[36,37]$} \\
\hline & Üveg & [38] & - & - & - & - & - & [39] & - & [40] \\
\hline
\end{tabular}

\subsection{Erốmúi pernye alkalmazása útépítési területen}

A pernye puccolános tulajdonságokkal rendelkezô, általában a cementnél finomabb szemcséket tartalmazó anyag. A pernyét vízzel keverve önmagában nem, viszont a kalcium-hidroxid jelenlétében hidraulikusan megszilárdul, azaz megköt. A pernyék puccolános tulajdonságait (aktivitását) a kémiai és fizikai sajátosságai határozzák meg, amelyek a következók:

- a pernyeszemcsék morfológiája,

- fajlagos felülete,

- szemcseméret-eloszlása, illetve

- a fázisösszetétele.

A puccolános aktivitása szerint (reakcióképesség szempontjából) a pernyében lévő $\mathrm{SiO}_{2}$ és $\mathrm{Al}_{2} \mathrm{O}_{3}$ mennyisége a mérvadó, de ez nem azonos a teljes $\mathrm{SiO}_{2}-\mathrm{Al}_{2} \mathrm{O}_{3}$ tartalommal. A pernye puccolános aktivitása nó, ha minél több reakcióképes $\mathrm{SiO}_{2}-\mathrm{Al}_{2} \mathrm{O}_{3}$ tartalommal rendelkezik az adott anyag. Morfológiai szempontból nagyrészt gömbölyú szemcsékkel rendelkezik. A szakirodalom alapján megkülönböztetnek savanyú (F-típusú) és bázikus pernyét (C-típusú) [1, 25]. A savanyú pernye 45-60\% $\mathrm{SiO}_{2}$-ot, míg kevesebb, mint $15 \%$ CaO-ot tartalmaz, melyból az aktív mésztartalom nem haladhatja meg a $10 \%$-ot. A bázikus pernyék mindössze 20-25\% $\mathrm{SiO}_{2}$-tartalommal bírnak, emellett 30-40\% CaO-dal rendelkeznek, melyból az aktív mésztartalom több lehet 10\%-nál [8, 41, 42].
Az erômúi pernyének számos potenciális felhasználási területei léteznek. Alkalmazásának lehetséges területeit négy fó kategóriába sorolják:

- építóanyagok (cement, beton, kerámia, üveg),

- geotechnikai alkalmazások (útburkolatok, töltések),

- "mezôgazdasági” terület (talajstabilizáció),

- egyéb (szorbens, iszapkezelés) [30].

Ahogyan azt az 1. ábra is szemlélteti, a pernyét útépítési anyagként már számos célra alkalmazták.

Megfigyelhetó, hogy a pernye alkalmazási területeinek több, mint 50\%-át az útépító ipar fedi le. Szakirodalmi adatok szerint a pernyét már alkalmazták az útépítóiparban töltésstabilizáló anyagként, alapréteg alapanyagaként, töltőanyagként, illetve bitumenes burkolatok anyagaként egyaránt. Az útpályaszerkezetek alkalmazásánál az esôzések során a pernye belsejébe a víz nem tud behatolni, ezáltal a nehéz fémek kioldódása nem okoz problémát. A pernye útépítési anyagként történó alkalmazása esetében az útburkolatok költségeit jelentốs mértékben lehetne csökkenteni [44].

Mohammadinia munkatársaival [15] a pernyét küIönbözô arányban használták zúzott téglával és visszanyert aszfalttal együtt újrahasznosított aszfaltburkolat stabilizálásához alsó teherhordó burkolat alapjaként. A próbatesteken nyomószilárdságot és rugalmassági modulust határoztak meg ( 7 napos korban). Az eredmények alapján a pernyével stabilizált zúzott tégla és visszanyert aszfalt szi- 


\section{3. táblázat. Másodlagos anyagok alkalmazása útépítési anyagként}

\begin{tabular}{|c|c|c|c|}
\hline Szerzók & Felhasznált anyag & Szemcseméret & Elért eredmény \\
\hline Wu et al. & nikkelsalak & $\mathrm{d}<80 \mu \mathrm{m}$ & $\begin{array}{l}3 \text { napos korban: } \\
R_{m, \min }=6,9 \mathrm{MPa}, R_{m, \max }=21,9 \mathrm{MPa} \\
28 \text { napos korban: } \\
R_{m, \min }=14,5 \mathrm{MPa} R_{m, \max }=52,4 \mathrm{MPa}\end{array}$ \\
\hline \multirow{3}{*}{$\begin{array}{l}\text { Mohammadinia } \\
\text { et al. }\end{array}$} & pernye & $\mathrm{d}_{50}<30 \mu \mathrm{m}$ & \multirow{3}{*}{$\begin{array}{l}\text { A szilárdsági tulajdonságok legfeljebb } \\
15 \mathrm{~m} / \mathrm{m} \% \text {-ban hozzáadott pernyével növelhe- } \\
\text { tók (>15 m/m\% szilárdságcsökkenést } \\
\text { eredményez) }\end{array}$} \\
\hline & zúzott tégla & $\mathrm{d}_{50}<600 \mu \mathrm{m}$ & \\
\hline & visszanyert aszfalt & $\mathrm{d}_{50}<400 \mu \mathrm{m}$ & \\
\hline Sobolev et al. & pernye (F típusú) & $\mathrm{d}<74 \mu \mathrm{m}$ & $\begin{array}{l}\text { Keverék teljesítménye } \uparrow \text {. A pernyeszemcsék a } \\
\text { dinamikus terhelések hatására kialakuló repe- } \\
\text { déseket elzárták. }\end{array}$ \\
\hline \multirow[t]{2}{*}{ Xu et al. } & erómúi pernye & $\mathrm{d}=0,76-61,61 \mu \mathrm{m}$ & \multirow{2}{*}{$\begin{array}{l}\text { A pernyével készített aszfaltkeverék Marshall- } \\
\text { stabilitása és nyomvályúsodással szembeni } \\
\text { ellenállása } \downarrow\end{array}$} \\
\hline & mészkóliszt & $\mathrm{d}=4,71-179,7 \mu \mathrm{m}$ & \\
\hline \multirow{2}{*}{$\begin{array}{l}\text { Likitlersuang } \\
\text { et al. }\end{array}$} & cement & $\mathrm{d}_{50}<11 \mu \mathrm{m}$ & \multirow[t]{2}{*}{ A keverék merevségi modulusa $\uparrow$} \\
\hline & lignittüzelésból származó pernye (C típusú) & $\mathrm{d}_{50}<19 \mu \mathrm{m}$ & \\
\hline \multirow{2}{*}{$\begin{array}{l}\text { Gómez-Meijide } \\
\text { et al. }\end{array}$} & \multirow[t]{2}{*}{ építési és bontási hulladék } & $12 / 24 \mathrm{~mm}$ & \multirow{2}{*}{$\begin{array}{l}\text { A keveréknek magasabb a hézagtérfogata. } \\
\text { Bitumenigény } \uparrow\end{array}$} \\
\hline & & $6 / 12 \mathrm{~mm}$ & \\
\hline \multirow[t]{3}{*}{ Arabani et al. } & dácit & \multirow[t]{3}{*}{$\mathrm{d}=0,074-19 \mathrm{~mm}$} & \multirow{3}{*}{$\begin{array}{l}\text { Mechanikai tulajdonságok } \downarrow \text {, } \\
\text { Marshall-stabilitás } \uparrow\end{array}$} \\
\hline & acélgyártási salak & & \\
\hline & visszanyert beton (Recycled concrete aggregate, RCA) & & \\
\hline Tao et al. & acélgyártási salak & $\mathrm{d}<75 \mu \mathrm{m}$ & $\begin{array}{l}\text { A salak, mint aszfalt töltóanyag növeli a ha- } \\
\text { barcs nyírási modulus értékét. Kombinálva } \\
\text { a salakot és mészkólisztet minimálisra csök- } \\
\text { kenthetó az aszfalt alacsony hómérsékletú } \\
\text { repedési ellenállása. }\end{array}$ \\
\hline \multirow[t]{3}{*}{ Pesetto et al. } & acélgyártási salak (két különböző összetétel) & \multirow[t]{3}{*}{$0 / 5,5 / 10,10 / 15 \mathrm{~mm}$} & \multirow{3}{*}{$\begin{array}{l}\text { Az acélgyártási salakkal készült keverék rend- } \\
\text { kívül pozitív hatással rendelkezik, mind a me- } \\
\text { revség és a fárasztási vizsgálat tekintetében }\end{array}$} \\
\hline & homok & & \\
\hline & mészkóliszt & & \\
\hline
\end{tabular}

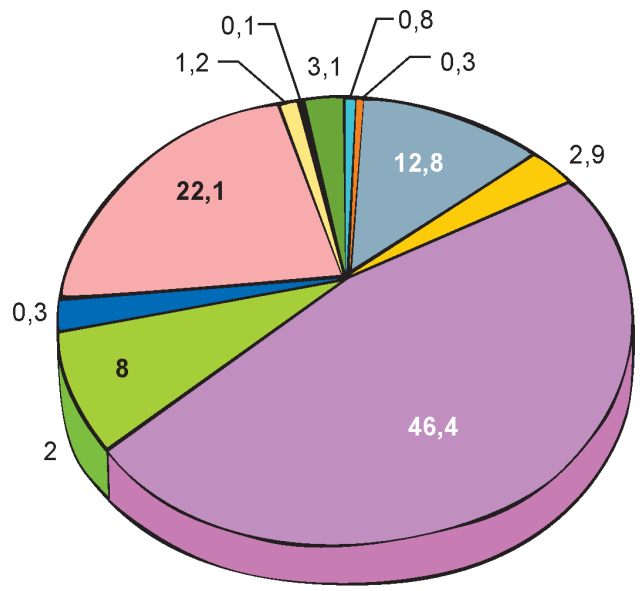

adalékanyag

bányászati alkalmazás

talajstabilitás

útburkolat

1. ábra. A pernye alkalmazásának aránya [43] lárdságuk és tartósságuk alapján életképesek útburkolati anyagként. A szilárdsági tulajdonságok legfeljebb 15 m/m\%-ban hozzáadott pernyével növelhetôk (>15 m/m\% szilárdsági romlást eredményez).

Sobolev és munkatársai [45] savanyú és bázikus pernye hatását vizsgálták a bitumenes anyagok reológiai tulajdonságaira. Eredményeik alapján megállapították, hogy a bitumenes anyagban célszerú alkalmazni a pernyét, ugyanis javítja a keverék teljesítményét. A szerzók mikroszerkezeti vizsgálattal kimutatták, hogy a bitumenes mátrixban egyenletesen eloszlatott pernyeszemcsék a dinamikus terhelések hatására kialakuló repedéseket elzárták.

Xu és munkatársai [46] szénerómúból származó pernye aszfalthabarcs keverékekben történó vizsgálatával foglalkoztak. Az eredmények alapján a pernye kisebb súrúséggel rendelkezik a mészkólisztnél (referencia 
anyag). A szénerômúi hulladék lúgosabb kémhatású, valamint finomabb szemeloszlással bír. A pernyét tartalmazó keverék alacsonyabb Marshall-stabilitást és nyomvályúsodással szembeni ellenállást mutat. Gazdasági szempontból kivitelezhetô a szénerómúi hulladék alkalmazása aszfaltkeverékben.

Likitlersuang és kollégái [23] cement és lignit tüzelésból származó (C típusú) pernye felhasználásával készítettek aszfaltbeton keverékeket, majd a keverék teljesítményének laboratóriumi vizsgálatával foglalkoztak. Eredményeik alapján megállapították, hogy a keverékek merevségi modulusa nótt a cement és pernye töltóanyagként történó hasznosításával.

Churchill és munkatársai [19] a közúti építés során felhasznált természeti eróforrások csökkentésének érdekében széntüzelésból származó pernye aszfaltbeton töltőanyagának helyettesítésével foglalkoztak. Kutatásaik során az aszfaltbeton próbatestek mechanikai tulajdonságait vizsgálták. Az eredményeik azt mutatták, hogy a töltőanyag frakció széntüzelésból származó pernyével történó részleges helyettesítése mérsékelten káros hatást gyakorolt a próbatestek szilárdságára. Ezzel szemben számos pernye/mész keverék eleget tett a minimális szilárdsági követelményeknek.

Mistry és társa [20] kutatómunkájukban azt vizsgálták, hogy az aszfaltkeverékben felhasznált pernye milyen hatással van a mészhidrát töltóanyag helyettesítésére. A kísérleti eredményeik szerint a mészhidrát pernyére történó cseréje nem csak a szabványban foglalt elóírásoknak tesz eleget, hanem jobb szilárdságot biztosít a hagyományos töltőanyaghoz képest.

További kutatások [21] során szilánnal kezelt pernyét vizsgáltak, valamint azok felhasználásával készítettek aszfaltkeverékeket, amelyeken a nedvesség hatására bekövetkezó tönkremeneteli jelenségeket tanulmányozták. Az eredményekból megállapították, hogy a modifikált pernye javította a vízérzékenységet, növelte a húzószilárdságot, a merevségi modulust, a fáradási ellenállást és a maradó alakváltozást is.

Ali és munkatársai [22] széntüzelésból származó pernyét használtak töltőanyagként aszfaltbeton keverékben. A mérési eredmények alapján megállapították, hogy a pernye alkalmazása célszerú, mivel javítja az aszfaltbeton szilárdsági tulajdonságait.

\subsection{Bányászati meddó alkalmazása útépítési területen}

Oluwasola és társai [10] elektroacél-gyártási salakot és rézbányászati meddót alkalmaztak hagyományos ásványi anyagok helyett autópályák anya- gaként. Az általuk készített keverékeken Marshallstabilitást, vízérzékenységet mértek, illetve a keverék laboratóriumi értékeléséhez meghatározták a reziliens modulust, majd dinamikus kúszási vizsgálatot is végrehajtottak. Az eredmények alapján arra a következtetésre jutottak, hogy javul az aszfaltkeverék teljesítménye, ha a gránitot, mint természetes adalékanyagot rézbányászati meddóvel és salakkal helyettesítik. Az eredmények kiértékelését követốen megállapították, hogy a bányászati melléktermék, illetve a kohászati hulladék anyag adalékanyagként alkalmazhatók az útépítésben. Giustozzi és munkatársai [11] mészkóliszt helyett két különböző helyrôl származó magnetit ásványi anyagot vizsgáltak töltőanyagként aszfaltkeverékekben. A magnetit olyan ásványi anyag, amely számos magmás kózetben, valamint folyami és tengeri környezetben is nagy mennyiségben megtalálható. Kísérleteik során a magnetitet és a mészkólisztet bitumenhez adagolták. Megvizsgálták a keverék reológiai tulajdonságainak hatását a magnetit, mint potenciális töltóanyag aszfaltkeverékben történő alkalmazási lehetôségeire. Továbbá szemcseméret-eloszlással, morfológiai elemzéssel (SEM, Cryo-SEM), és energiadiszperzív röntgenspektroszkópiával jellemezték a keveréket. Elért eredményeik alapján megállapították, hogy a magnetit alapú ferromágneses töltóanyag (amely számos országban nagy mennyiségében áll rendelkezésre) újrahasznosításának megfelelő módja az anyag aszfaltkeverékbe történő felhasználása. A hómérséklet növelésével a keverék merevsége és rugalmas viselkedése javult, ezáltal potenciálisan növekszik a burkolat állandó deformációval szembeni ellenállása.

Wang és társai [12] magnetit meddót használtak mészkóliszt helyettesító adalékanyagként. A vizsgálati eredményeik alapján megállapították, hogy a magnetit meddó nem tartalmaz nehézfémet és nincs jele a toxikus szennyezés veszélyeinek sem. A mészhidrát a magnetittel javítja az aszfalt adalékanyag tapadását és az aszfaltkeverékek vízérzékenységét. Eredményeik alapján kijelenthető, hogy a magnetit meddót tartalmazó aszfaltkeverékek kiváló tulajdonságokkal rendelkeznek, ezáltal a természetes adalékanyagok aszfaltban történó helyettesítésére alkalmasak.

Dhir és munkatársai [13] olajfúrásból származó, tisztított meddőt vizsgáltak, melyet aszfalt töltóanyagként kívántak hasznosítani. Az anyagok geometriai, fizikai és kémiai tulajdonságainak vizsgálata mellett általános aszfalttechnológiai teszteket is elvégeztek. Kutatásaik során referenciaanyagként mészkólisztet használtak. Az eredmények kiértékelését követốn megállapították, hogy az olajfúrásból származó meddó anyag egyik lehetséges felhasználási területe lehet az útépítés. 


\subsection{Kohászati salakok alkalmazása útépítési területen}

A kohászati salakok elhelyezése világszerte növekvő problémát jelent. A World Steel Association 2016-os adatai alapján Kína (49,5\%) és Európa $(10,2 \%)$ áll a nyersacél termelés élén [2].

Az utóbbi évtizedben Magyarországon is nagy mennyiségben megnövekedett az alumínium ötvözetek felhasználása, melynek következtében jelentốs mennyiségú alumínium öntészeti salak keletkezik. A 3. táblázatban megfigyelhetô Magyarország alumíniumöntvény termelésének alakulása 2007 és 2014 közötti idôszakban. A táblázat adatai szerint 2010-tôl folyamatosan nótt az alumíniumtermékek előállítása.

Irodalmi adatok [48] támasztják alá azt a tényt, hogy a kohászati folyamatokból nyert salakok kiváló eredményeket mutatnak az aszfaltkeverékekben felhasznált szerepük alapján. A kohósalak javítja az útburkolat jármúvek okozta deformációjával szembeni ellenállását és kifáradását. A salakok alkalmazásával javíthatók a jármúvek és az útburkolatok közötti súrlódási tulajdonságok (kopás), valamint az útburkolati hibák (pl. nyomvályúsodás, repedés) kialakulása is csökkenthető.

Wu és társai [49] kutatómunkájukban nikkelsalakot használtak útépítési nyersanyagként portlandcement elóállításhoz. A klinkerásványok és a hidratációs termékek morfológiáját metallográfiai és pásztázó elektronmikroszkóppal vizsgálták. Az eredményeik azt mutatták, hogy a nikkel salak hozzáadásával csökkent a klinker CaO-tartalma és javult a nyersliszt égethetôsége. Emellett a nikkel salak növelte a cementpép hidratációs fokát és hajlítószilárdságát. A szerzốk megállapították, hogy a nikkel salak alkalmas cement elóállításra. A nyomószilárdsági eredmények 3 napos korban 6,9 $\mathrm{MPa}-21,9 \mathrm{MPa}$, míg 28 napos korban 14,5 MPa 52,4 MPa között változott.

Pasetto és társa [50] aszfaltbeton keverékeken végeztek laboratóriumi vizsgálatokat, melyeket három különbözố kötőanyaggal és négy féle adalékanyaggal készítettek el. Munkájuk során kétféle összetétellel rendelkezô acélgyártási salakot, homokot és mészkólisztet használtak fel. Kísérleti eredményeik alapján megállapították, hogy a fizi- kai és mechanikai jellemzók szerint az acélgyártási salakok megegyeznek a közlekedési infrastruktúrában leggyakrabban használt természetes kóanyagok jellemzóivel. A salakkal készült keverék rendkívül pozitív hatással bír, mind a merevség, mind a fárasztási vizsgálatok tekintetében.

Tao és társai [51] szintén acélgyártási salakot használtak aszfalkeverékek töltőanyagaként, melyek reológiai tulajdonságainak hatását vizsgálták. Pásztázó elektronmikroszkópos vizsgálataik eredménye szerint az acélgyártási salak ốrlemény felületén számos pórus található $(0,5-5 \mu \mathrm{m})$, míg a mészkóliszt felülete sima. Oxidos összetételvizsgálattal kimutatták, hogy mindkét anyag fó alkotója a $\mathrm{CaO}$ és a $\mathrm{SiO}_{2}$, de bizonyos mennyiségben tartalmaznak $\mathrm{Fe}_{2} \mathrm{O}_{3}$ és egyéb más oxidokat is. A salak, mint aszfalt töltóanyag növeli a habarcs nyírási modulusának értékét. Kombinálva a salakot és mészkólisztet minimálisra csökkenthetó az aszfalt alacsony hômérsékletú repedési ellenállása.

Mailar és társai [52] kutatási eredményei azt igazolták, hogy a megfeleló mennyiségben újrahasznosított alumínium salak a beton készítéséhez szükséges cement részleges cseréjére, kiváltására alkalmas. A cement salakkal történó megfeleló arányú cseréje javítja a beton pórusszerkezetét, szilárdságát, a sókkal szembeni ellenállóképességét, illetve szulfátállóságát.

Li és munkatársai [53] kísérleteik során finomszemcsés acélgyártási salak hatását vizsgálták aszfalthabarcsokon. Kontrollvizsgálatokat is elvégeztek mészkóliszttel készített keverékeken. Megfigyelték, hogy alacsony hômérsékleten az acélgyártási salak felhasználásával készített aszfalthabarcsok - magasabb CaO-tartalmuk és nagyobb fajlagos felületük következtében - több aszfaltént képesek lekötni, ezáltal nagyobb repedéssel szembeni ellenállóképességet biztosítanak az aszfalthabarcsnak alacsony hómérsékleten. Emellett a finomabb salakszemcsék növelik a szakadással szembeni ellenállást is. Ennek okát a húzás során kialakuló feszültségkoncentrációk különbözôségében látták.

Masoudi és társai [54] kutatómunkájuk során az elektroacélmúi salak hasznosíthatóságát vizsgálták a meleg aszfaltkeverékek hosszú távú teljesítményére. A természetes ásványi anyagokat a salak-

3. táblázat. Magyarország alumíniumöntvény termelése 2007 és 2014 között [47]

\begin{tabular}{|c|c|c|c|c|}
\hline \multirow[t]{2}{*}{ Megnevezés } & \multicolumn{4}{|c|}{ Öntvénytermelés (tonna) } \\
\hline & 2007 & 2010 & 2011 & 2014 \\
\hline Alumínium kokillaöntvény & 53919 & 46323 & 43721 & 49604 \\
\hline Alumínium nyomásos öntvény & 43011 & 42898 & 55448 & 51658 \\
\hline Alumínium homoköntvény & 343 & 202 & 243 & 161 \\
\hline Összes alumíniumöntvény & 97276 & 88921 & 99412 & 101423 \\
\hline
\end{tabular}


kal, mint másodlagos nyersanyaggal kívánták kiváltani. Kutatómunkájuk eredményeként megállapították, hogy az acélgyártási salakot tartalmazó keverék kevésbé öregedett, mint a referenciaanyagot (mészkólisztet) tartalmazó keverék.

\section{4 Építési hulladékok alkalmazása útépítési területen}

Az építési-bontási hulladékok (Construction and Demolition Waste, CDW) újrahasznosítását három szempont szerint határozzák meg:

- múszaki minóség,

- környezettel való összeegyeztethetôség, illetve

- az elsódleges ásványi anyagokkal való versenyképesség.

Az építési másodlagos anyagok felhasználása történhet közvetlenül, valamint közvetetten. A közvetlen újrahasznosítást elsósorban a kitermelt talajok esetén alkalmazzák, míg a közvetett hasznosítást valamilyen elókészítési folyamat elózi meg. Számos kutatásban foglalkoztak már a téglaórleménnyel, mint újrahasznosított aszfalt töltôanyaggal [32, 54-57]. Chen és munkatársai [32] összehasonlító elemzéseket végeztek, amelyben a primer kózetként alkalmazott mészkólisztet és az alternatív anyagként használt téglaórleményt vizsgálták. A töltóanyagokon elvégzett anyagszerkezeti vizsgálatokat követóen aszfaltkeverékeket készítettek. Kísérleti eredményeik alapján arra jutottak, hogy a téglaórleménnyel készített aszfaltkeverékek javítják a burkolat nyomvályúsodással szembeni ellenállását, a vízérzékenységet, valamint a fáradási tulajdonságokat.

Gómez-Meijide és kollégái [58] építési és bontási hulladékból készítettek hideg aszfaltkeveréket, amelyen merevségi tulajdonságokat vizsgáltak. Kutatómunkájuk során azt tapasztalták, hogy az aszfaltkeverék magasabb szabad hézaggal rendelkezett, ami elónyös lehet porózus aszfalt készítése szempontjából. Ugyanakkor az építési és bontási hulladékból készült keverék több bitument igényelt a keverékkészítés során. A szerzók vizsgálataik alapján megállapították, hogy az építési és bontási hulladék anyagból készített hideg aszfaltkeverék jól alkalmazható gyengébb forgalmú utakhoz.

Több tanulmány is foglalkozik újrahasznosított betonôrlemény útépítési anyagként történő alkalmazásával [31,59]. Ezek a kutatások jellemzóen az újrahasznosított betonórlemény aszfaltkeverékben történő alkalmazását vizsgálták. A vizsgálati eredmények szerint a referenciaanyaghoz (mészkóliszthez) képest javulást figyeltek meg az aszfaltkeverékek vízérzékenysége és a fáradási ellenállása során.
Arabani és munkatársai [33] tanulmányának célja a visszanyert beton (Recycled concrete aggregate, RCA) és az acélgyártási salak adalékanyagként történó hatásainak vizsgálata melegaszfaltban. Az aszfaltkeverékben dácit kózetet RCA-ra cserélve nagymértékben romlottak a keverék mechanikai tulajdonságai. Az RCA finom adalékanyagként, illetve az acélgyártási salak finom, vagy durva adalékként történó alkalmazása esetén nőtt a keverék Marshall-stabilitása. Az optimális aszfaltbeton keverékük töltóanyagként dácitot, finom adalékként RCA-t és durva adalékanyagként acélgyártási salakot tartalmazott.

\section{3. Összegzés}

Jelen cikk a másodlagos nyersanyagok, illetve más típusú hulladékok útépítési anyagaként történó hasznosítási lehetôségeivel foglalkozó irodalmi ismereteket kívánta bemutatni, ismertetve a legújabb kutatási eredményeket. Nem szabad elmenni amellett a tény mellett, hogy a különbözó gyártási technológiák eredményeként keletkezó hulladékok is az emberi igények kielégítésének hatására folyamatosan termelódnek, mennyiségük rohamosan nó. A hulladéklerakókban történó tárolásuk nem jelent végleges megoldást, hiszen ez sem gazdaságilag, sem pedig környezetvédelmi szempontból nem elönyös. Emiatt újrahasznosításuk nélkülözhetetlen, melynek egyik potenciális területe az útépítés.

\section{Köszönetnyilvánítás}

Jelen kutatómunka az Európai Szociális alap és Magyarország Kormányának társfinanszírozásával valósul meg a „Fenntartható Nyersanyag-gazdálkodási Tematikus Hálózat - RING 2017" címú EFOP-3.6.2-16-2017-00010 azonosító számú projekt keretén belül.

\section{Felhasznált irodalom}

[1] Anupam K, Kumar P, Ransinchung G. Use of Various Agricultural and Industrial Waste Materials in Road Construction. Procedia-Social and Behavioral Science. 2013 December; 104:264-273. https://doi.org/10.1016/j.sbspro.2013.11.119

[2] Guo J, Bao Y, Wang M. Steel slag in China: Treatment, recycling, and management. Waste Management. 2018 August, 79: 318-330.

https://doi.org/10.1016/j.wasman.2018.04.045

[3] Wang G) 14 - Case studies on slag utilization. The Utilization of Slag in Civil Infrastructure Construction. 2016; 339-370.

https://doi.org/10.1016/B978-0-08-100381-7.00014-8

[4] Wang G. 8 - Unbound slag aggregate use in construction. The Utilization of Slag in Civil Infrastructure 
Construction. 2016;155-184.

https://doi.org/10.1016/B978-0-08-100381-7.00008-2

[5] Bornemissza T, Bóhm J, Csóke B, Erôs Gy, Gáspár L, Horváth A, Karoliny M, Lengyel A, Molnár J, Ruppert L, Vámos Gy, Záray Gy. Másodlagos nyersanyagok az útépítésben. IHU Kht. Kiadó, 2005; 255.

[6] Építési és bontási hulladék. http://www.kvvm.hu/szakmai/hulladekgazd/ hulladekgazdalkodas/hulladektipusok_epit_bont.htm Megtekintés ideje: 2018. 11. 20.

[7] Csóke B. Ipari hulladékok elókészítése és hasznosítása. http://hulladekonline.hu/files/178/

[8] Mucsi G: Erómúi pernye komplex hasznosítása. http://kritikuselemek.uni-miskolc.hu/files/ files/monografia_6(1).pdf

Megtekintés ideje: 2019.01. 07.

[9] http://ec.europa.eu/environment/waste/ construction_demolition.htm Megtekintés ideje: 2018. 11. 20.

[10] Oluwasola E, Hainin M, Aziz MMR. Evaluation of asphalt mixtures incorporating electric arc furnace steel slag and copper mine tailings for road construction. Transportation Geotechnics. 2015 March; 2:47-55. https://doi.org/10.1016/j.trgeo.2014.09.004

[11] Giustozzi F, Mansour K, Patti F, et al. Shear rheology and microstructure of mining material-bitumen composites as filler replacement in asphalt mastics. Construction and Building Materials. 2018 May; 171:726-735. https://doi.org/10.1016/j.conbuildmat.2018.03.190

[12] Wang Z, Xu C, Wang S, et al. Utilization of magnetite tailings as aggregates in asphalt mixtures, Construction and Building Materials. 2016 July; 114:392-399. https://doi.org/10.1016/j.conbuildmat.2016.03.139

[13] Dhir R, Csetenyi L, Dyer T, et al. Cleaned oil-drill cuttings for use as filler in bituminous mixtures. Construction and Building Materials. 2010, March; 24:322-325. https://doi.org/10.1016/j.conbuildmat.2009.08.022

[14] Ahmed I, Lovell CW. Use of Waste Materials Used in Highway Construction 1st Edition. Imprint William Andrew, 1993; 125. eBook ISBN9780815519461

[15] Mohammadinia A. (2017) Effect of fly ash on properties of crushed brick and reclaimed asphalt in pavement base/subbase applications. Journal of Hazardous Material. 2017 January; 321(5):547-556. http://dx.doi.org/10.1016/j.jhazmat.2016.09.039

[16] Dwivedi A, Jain M. Fly ash-waste management and overview: A review. Recent Research in Science and Technology. 2014 August; 6:30-35.

[17] Miloš Š, Nebojša R, Nikolay V. Construction of Road Embankment with Waste Materials. Applied Mechanics and Materials. 2015 January; 725-726:596-601. https://doi.org/10.4028/www.scientific.net/ AMM.725-726.596

[18] https://www.fhwa.dot.gov/pavement/recycling/ fach06.cfm

Megtekintés ideje: 2019.01. 31.

[19] Churchill EV, Amirkhanian SN.Coal ash utilization in asphalt contrete mixtures. Journal of Materials in Civil Engineering. 1999 November; 11 (Is.4):295-301. https://doi.org/10.1061/(ASCE)0899-1561(1999) $11: 4(295)$

[20] Mistry R, Roy T. Effect of using fly ash as alternative filler in hot mix asphalt. Perspectives in Science. 2016
September; 8:307-309.

http://doi.org/10.1016/j.pisc.2016.04.061

[21] Xie SW, J, Pang, L, Lin, J, Zhu, Z. Influence of surface treated fly ash with coupling agent on asphalt mixture moisture damage. Construction and Building Materials. 2012 May; 30:340-346. https://doi.org/10.1016/j.conbuildmat.2011.11.022

[22] Ali N, Chen J, Simms S, et al. Mechanistic evaluation fly ash asphalt concrete mixtures. Journal of Materials in $\mathrm{Ci}$ vil Engineering. 1996 February; 8(Is.1):19-25. https://doi.org/10.1061/(ASCE)0899-1561(1996)8:1(19)

[23] Likitlersuang S, Chompoorat T. Laboratory investigation of the performances of cement and fly ash modified asphalt concrete mixtures. International Journal of Pavement Research and Technology. 2016 September; 9(Is.5):337-344.

http://doi.org/10.1016/j.ijprt.2016.08.002

[24] Sobolev K, Vivian IF, Saha R, et al. The effect of fly ash on the rheological properties of bituminous materials. Fuel. 2014 January; 116:471-477. http://dx.doi.org/10.1016/j.fuel.2013.07.123

[25] Saritha N. A Study on use of Carbon Black Powder in Bituminous Road Construction. International Journal of Engineering Research \& Technology. 2015 June; 4:76-83, ISSN2278-0181.

https://doi.org/10.17577/ijertv4is060220

[26] Mohd RH, Maniruzzaman A, Zulfiqar A, Ramadhansyah PJ, Moetaz MS, Haryati Y. Steel Slag as A Road Construction Material. Journal Teknologi (Sciences and Engineering). 2015 January; 73(4):33-38. eISSN2180-3722

[27] Pasetto M, Baldo N. Experimental evaluation of high performance base course and road base asphalt concrete with electric arc furnace steel slags. Journal of Hazardous Materials. 2010 September; 181:938-948. https://doi.org/10.1016/j.jhazmat.2010.05.104

[28] Busari AA, Akinwumi I, Awoyera PO, Olofinnade OM, Tenebe TI, Nwanchukwu JC. Stabilization Effect of Aluminum Dross on Tropical Lateritic Soil. International Journal of Engineering Research in Africa. 2018 November; 39:86-96.

https://doi.org/10.4028/www.scientific.net/JERA.39.86

[29] Soós Z, Géber R, Tóth Cs, Igazvölgyi Zs, Udvardi B. Utilization of aluminium dross as asphalt filler. Journal of Silicate Based and Composite Materials. 2017 March; 69(3):89-93.

https://doi.org/10.14382/epitoanyag-jsbcm.2017.15

[30] Saravanan S, Venkatasubramanian C, Muthu D, Ramakrishnan K. Construction of Rural Roads using C\&D Waste Materials. Indian Journal of Science and Technology. 2016 July; 9(27):1-5. http://dx.doi.org/10.17485/ijst/2016/v9i27/97634

[31] Chen, M, Lin, J, Wu, S. Potential of recycled fine aggregates powder as filler in asphalt mixture. Construction and Building Materials. 2011 October 2011; 25(10):3909-3914. https://doi.org/10.1016/j.conbuildmat.2011.04.022

[32] Chen M, Lin J, Wu S, Liu C. Utilization of recycled brick powder as alternative filler in asphalt mixture. Construction and Building Materials. 2011 April; 25(4): 1532-1536. https://doi.org/10.1016/j.conbuildmat.2010.08.005

[33] Arabani M, Azarhoosh AR. The effect of recycled concrete aggregate and steel slag on the dynamic properties of asphalt mixtures. Construction and Building Materials. 
2012 October; 35:1-7.

https://doi.org/10.1016/j.conbuildmat.2012.02.036

[34] Hou Y, Ji X, Li J, Li X. Adhesion between Asphalt and Recycled Concrete Aggregate and Its Impact on the Properties of Asphalt Mixture. Materials. 2018 December; 11(12):1-15. https://doi.org/10.3390/ma11122528

[35] Rodríguez-Fernández I, Lastra-González P, IndacoecheaVega I, Castro-Fresno D. Recyclability potential of asphalt mixes containing reclaimed asphalt pavement and industrial by-products. Construction and Building Materials. 2018 November; 195:148-155. https://doi.org/10.1016/j.conbuildmat.2018.11.069

[36] Fernandes SRM, Silva H, Oliveira J. Recycled stone mastic asphalt mixtures incorporating high rates of waste materials. Construction and Building Materials. 2018 October; 187:1-13.

https://doi.org/10.1016/j.conbuildmat.2018.07.157

[37] Mhlongo SM, Abiola OS, Ndambuki JM, Kupolati WK. Use of Recycled Asphalt Materials for Sustainable Construction and Rehabilitation of Roads. International Conference on Biological, Civil and Environmental Engineering. 2014; 91-94.

http://dx.doi.org/10.15242/IICBE.C0314157

[38] Disfani MM, Arulrajah A, Bo MW, Hankour R. Recycled crushed glass in road work applications. Waste Management. 2011 November; 31(11):2341-2351. https://doi.org/10.1016/j.wasman.2011.07.003

[39] Pasetto $M$, Baldo $N$. Resistance to Permanent Deformation of Road and Airport High Performance Asphalt Concrete Base Courses. Advanced Materials Research. 2013 August; 73:494-502.

https://doi.org/10.4028/www.scientific.net/

AMR.723.494

[40] Lou J, Liu H, Pang A, Sun H, Yang S, Yang T. The High Temperature Stability of Asphalt Composite Reinforced by Basalt Glass Powder and Basalt Fiber. Advanced Materials Research. 2012 December; 627:813-815. https://doi.org/10.4028/www.scientific.net/ AMR.627.813

[41] Szilágyi K, Gömze AL, Polacsek G. A pernye bekeverési arányainak vizsgálata, meghatározása a gyártott cement mechanikai tulajdonságainak optimalizálása céljából. Journal of Silicate Based and Composite Materials. 2008 August; 60:44-49. http://doi.org/10.14382/epitoanyag-jsbcm.2008.9

[42] Opocky L. A pernyék szilikátkémiai tulajdonságai. http://hulladekonline.hu/files/166/ Megtekintés ideje: 2019.01. 07.

[43] https://www.slideshare.net/JyotiKumari70/ flyash-disposal-and-utilization-69528633 Megtekintés ideje: 2019. 02. 14.

[44] Ahmaruzzaman M. A review on the utilization of fly ash. Progress in Energy and Combustion Science. 2009 December: $36: 327-363$

[45] Sobolev K, Vivian IF, Sah R et al. The effect of fly ash on the rheological properties of bituminous materials. Fuel. 2014 January; 116:471-477. http://dx.doi.org/10.1016/j.fuel.2013.07.123

[46] Xu P, Shi, Chen Z, Cai J, Pei J, Gao J, Zhang J, Zhang J. The effect of retreated coal wastes as filler on the performance of asphalt mastics and mixtures. Construction and Building Materials. 2019 January; 203:9-17. https://doi.org/10.1016/j.conbuildmat.2019.01.088
[47] http://www.innoteka.hu/cikk/egy_alig_ismert sikeragazat_onteszet.1228.html Megtekintés: 2019.03.19.

[48] Yi H, Xu G, Cheng H, Wang J, Wan Y, Chen H. An overview of utilization of steel slag. Procedia Environmental Sciences. 2012;16:791-801. https://doi.org/10.1016/j.proenv.2012.10.108

[49] Wu Q, Wu, Y, Tong W, Ma H. Utilization of nickel slag as raw material in the production of Portland cement for road construction. Construction and Building Materials. 2018 December; 193:426-434. https://doi.org/10.1016/j.conbuildmat.2018.10.109

[50] Pasetto M, Baldo N. Resistance to Permanent Deformation of Road and Airport High Performance Asphalt Concrete Base Courses. Advanced Materials Research. 2013 August; 723:494-502.

https://doi.org/10.4028/www.scientific.net/ AMR.723.494

[51] Tao G, Xiao Y, Yang L, Cui P, Kong D, Xue Y. Characteristics of steel slag filler and its influence on rheological properties of asphalt mortar. Construction and Building Materials. 2019 March; 2019, 201:439-446, https://doi.org/10.1016/j.conbuildmat.2018.12.174

[52] Mailar G, Raghavendra SN, Sreedhara BM, Manu DS Hiremath $P$, Jayakesh $K$. Investigation of concrete produced using recycled aluminium dross for hot weather concreting conditions. Resource-Efficient Technologies. 2016 June; 2:68-80. https://doi.org/10.1016/j.reffit.2016.06.006

[53] Li Q, Qiu Y, Rahman A, et al. Application of Steel Slag Powder to Enhance the Low-temperature Fracture Properties of Asphalt Mastic and its Corresponding Mechanism. Journal of Cleaner Production.2018 May; 184:21-31. http://doi.org/10.1016/j.jclepro.2018.02.245

[54] Masoudi S, Abtahi S, Goli A. Evaluation of electric arc furnace steel slag coarse aggregate in warm mix asphalt subjected to long-term aging. Construction and Building Materials. 2017 March; 135:260-266. http://dx.doi.org/10.1016/j.conbuildmat.2016.12.177

[55.] Wu S, Zhu J, Zhong J. et al. Experimental investigation on related properties of asphalt mastic containing recycled red brick powder. Construction and Building Materials. 2011 June; 25:2883-2887.

http://dx.doi.org/10.1016/j.conbuildmat.2010.12.040

[56] Aliabdo A, Hassan H. Utilization of crushed clay brick in concrete industry. Alexandria Engineering Journal. 2014 March; 53:151-168. http://dx.doi.org/10.1016/j.aej.2013.12.003

[57] Bilgin, N, Yeprem, H, Arslan, S. et al. (2012) Use of waste marble powder in brick industry. Construction and Building Materials.2012 April; 29:449-457. http://doi.org/10.1016/j.conbuildmat.2011.10.011

[58] Gómez-Meijide B, Pérez I, Airey G, Thom N. Stiffness of cold asphalt mixtures with recycled aggregates from construction and demolition waste. Construction and Building Materials. 2015 February; 77:168-178. https://doi.org/10.1016/j.conbuildmat.2014.12.045

[59] Bhusal S, Li X, Wen H. Evaluation of Effects of Recycled Concrete Aggregate on Volumetrics of Hot-Mix Asphalt. Journal of the Transportation Research Board. 2011; 2205:36-39. http://doi.org/10.3141/2205-05 